\title{
The Impact of Turbidity on Zooplankton Densities in Lake Kinneret (Israel)
}

\author{
Moshe Gophen \\ Migal Scientific Research Institute, Kiryat Shmone, Israel \\ Email: Gophe@Migal.org.il
}

Received 11 August 2015; accepted 21 September 2015; published 24 September 2015

Copyright (C) 2015 by author and Scientific Research Publishing Inc.

This work is licensed under the Creative Commons Attribution International License (CC BY). http://creativecommons.org/licenses/by/4.0/

c) (i) Open Access

\begin{abstract}
Spatial survey of zooplankton community composition within the upper 10 m layer in Lake Kinneret was carried out. Samples were collected by plankton net (63 $\mu$ mesh size) and counted organisms were sorted by 2 groups: 1) Large-including Copepodite and adult Cyclopoid copepods and Cladocerans; 2) Small nauplii and rotifers. It was found that in the northern part of the lake where turbidity is high, the density of small organisms is relatively lower, and in other parts of the lake where water is less turbid, large organisms are relatively less abundant. Speculative assumption about the impact of fish feeding behavior on that is presented.
\end{abstract}

\section{Keywords}

Lake Kinneret, Zooplankton, Spatial Distribution

\section{Introduction}

The study of spatial distribution of plankton in Lake Kinneret was documented previously [1] [2]. Their [1] [2] documented findings are based on low number of sampling points with mathematical evaluation which covered the whole Lake Surface area excluding shallows. Moreover, the evaluated distribution does not include speculative approach between the different food web compartment. The vertical and horizontal structure of thermal features in Lake Kinneret was intensively studied as well. In the present paper I have focused only on one parameter-the relative (\%) composition of large and small size zooplankters in 11 sites over the entire surface of Lake Kinneret (excl. shallows). The previously documented information on Lake Kinneret fish feeding habits was combined with respective linkage between zooplankton assemblages composition and fish feeding habits.

\section{Material and Methods}

Samples were collected by a double (down and up) tows of plankton net (63 $\mu$ mesh size. 25 cm diameter of open 
top side) from surface down to $10 \mathrm{~m}$ and back to surface. The total volume of filtered lake water is approximated as $1 \mathrm{~m}^{3}$ : net-open-surface $=\left\{(0.25 / 2)^{2} \times 3.14\right\} \times(10 \times 2)=$ app. $1 \mathrm{~m}^{3}$. Number of howls was $3-7$ within each station area at a distance of $200 \mathrm{~m}$ from points and counted separately. The sampling was carried out during winter time when the lake was over turned after several days of heavy rain and floods in the drainage basin followed by high discharge and turbulence flows in rivers. Total number of stations was 11 (See Map; Figure 1). Fifty one plankton samples (tows) were collected. The plankton samples were flushed externally by lake water from the distal bucket into jars. The total volume in the Jar was completed by filtered (63 $\mu$ mesh) lake water to 100 ml including $5 \mathrm{ml}$ of $10 \%$ formaldehyde that were added. Five Subsamples of $0.5 \mathrm{ml}$ each were removed while mixing and the total number of organisms in it was recorded and averaged as one value per station (SD $<20 \%$ of final result).

\section{Results}

The numerical percentages of different groups (Rotifera, Cladocera, Nauplius, Cyclopoid Copepodites and adult males and females) were computed (Table 1). Averages were calculated for each station area and the spatial

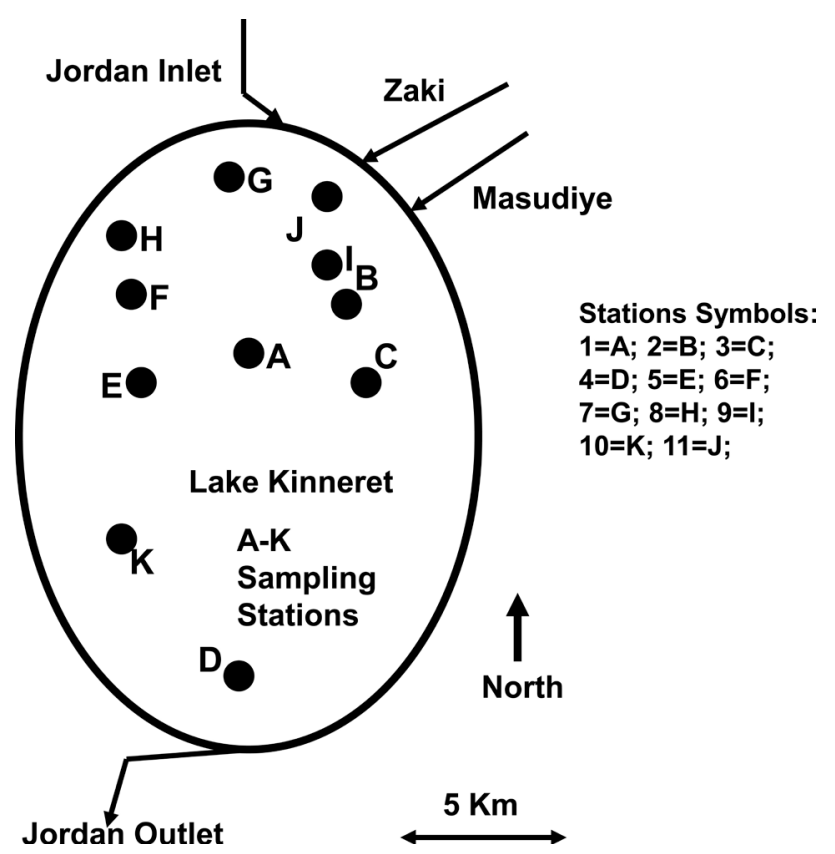

Figure 1. Schematic map chart of Lake Kinneret and sampling stations.

Table 1. Averages of numerical \% of 4 zooplankton groups and total mean (SD).

\begin{tabular}{ccccc}
\hline Station Number \& Symbol & Cyclopoid Nauplius & Cyclopoid Copepodite + Adults & Cladocera & Rotifera \\
\hline $1=$ A & 56 & 8 & 4 & 32 \\
$2=$ B & 45 & 10 & 5 & 40 \\
$3=$ C & 44 & 6 & 8 & 43 \\
$4=\mathrm{D}$ & 46 & 6 & 7 & 42 \\
$5=\mathrm{E}$ & 45 & 6 & 8 & 42 \\
$6=\mathrm{F}$ & 50 & 8 & 11 & 32 \\
$7=\mathrm{G}$ & 51 & 9 & 14 & 26 \\
$8=\mathrm{H}$ & 43 & 7 & 11 & 39 \\
$9=\mathrm{I}$ & 43 & 10 & 8 & 40 \\
$10=\mathrm{J}$ & 46 & 8 & 6 & 40 \\
$11=\mathrm{K}$ & 45 & 12 & 4 & 39 \\
Average (SD) & $46(7)$ & $8(3)$ & $8(5)$ & $38(8)$ \\
\hline
\end{tabular}


distribution analyzed respectively. Table 1 represent numerical \% composition of the zooplankton groups averaged for each station site (grand total average (SD) is given.

The total average of organisms number in all samples from all stations was 299 (SD = 109). Consequently number of organisms in sample can be summarized as 138 nauplius, 24 Cyclopoid copepods (Copepodite, Adults), 24 cladocerans and 114 rotifers. The actual zooplankton biomass density in the lake is approximated respective to $1 \mathrm{~m}^{3}$ and biomass values previously published [3]. The benefit of the present survey is the relative (\%) spatial distribution of zooplankton communities given comparatively in numerical and biomass (biovolume) units. Usage of Biovolume (Biomass) values were [3]: Nauplius (small and large) - $0.6 \mu \mathrm{g} / \mathrm{Ind}$; Rotifers -2 $\mu \mathrm{g} / \mathrm{Ind}$; Cladocerans $-25 \mu \mathrm{g} / \mathrm{Ind}$; Adult and Copepodite of Cyclopoid copepods $-20 \mu \mathrm{g} / \mathrm{Ind}$. Consequently the mass composition of an averaged sample in this survey is the following: 138 nauplius - $86 \mu \mathrm{g}$ ( $6 \%$ of total biomass); Copepodite and Adult Cyclopoid—480 $\mu \mathrm{g}$ (34\% of total biomass); Cladocera $-600 \mu \mathrm{g}$ (44\% of total biomass); and Rotifers-228 $\mu \mathrm{g}$ (16\% of total biomas). Two major outcomes are prominent: 1$)$ Numerical composition might be sufficient for pure spatial distribution study, but 2) insufficient for the evaluation of energy flow patterns and comprehensive lake metabolism research where additional values like biomass are essential. ANOVA $(\mathrm{p}<0.05)$ Comparative Test that was evaluated between the stations indicated prominently significant high percentage of Nauplius, Cladocera and large Cyclopoid copepods (Copepodite and adults) in stations G,F, A and to a lesser extent in B. I, and K. Significant low densities (by \%) of Rotifers were recorded in Stations F and G. A prominent significant (p ranged between 0.0014 and 0.0295) high densities (by \%) of Large organisms (Cladocerans and adult Cyclopoid Copepods) were documented in Station G (Figure 2, Figure 3). It is suggested that the impact of filter feeders fish in turbid (Jordan and other river inflows of suspended matters) waters is higher than in clear water stations and particulate visual attack feeding habits of fish is more intensive. In other words, in the turbid part of the lake the impact of filter feeding fishes is higher than in clear water parts where the dominant influence is due to Visual Particulate feeders fishes. Results in Figure 1 indicates higher percentage of large body zooplankters (Copepodite and Adult Cyclopoids and Cladocerans) in the river mouth areas of the Jordan, Zaki and Masudiye, (stations 6 - 9, Figure 1) where small organisms (Rotifera and Nauplii) were less abundant. This part of the lake as well as the West-Northern (stations H,F) [4] is more turbid than other parts of the lake resulted by the input of suspended matter from rivers whilst further to south these particles are dissipated by sedimentation [4]. In Figure 2 the low \% of rotifers and high densities of Cladocera in stations F, and G (Rotifera) and F,G, and H (Cladocera) are prominently indicated, the decline of rotifers is obviously accompanied by cladocerans elevation.

\section{Filter and Particulate Feeding by Lake Kinneret Fishes}

Feeding habits of the Lake Kinneret fishes were intensively studied. These studies were carried out by three major procedures: 1) Direct observation on fishes in captivity where observed free swimming zooplankton was attacked and successfully preyed upon by individual fish and was recorded for the calculation of "Capture Probability"; 2) Recorded number and measured size (TL ,W) of fishes were placed in containers filled with filtered (63 $\mu$ mesh) and given equal quota of freshly collected lake zooplankton; the rate of the elimination of zooplankton species by fish predation and consideration of zooplankton native mortality measured in Fishless

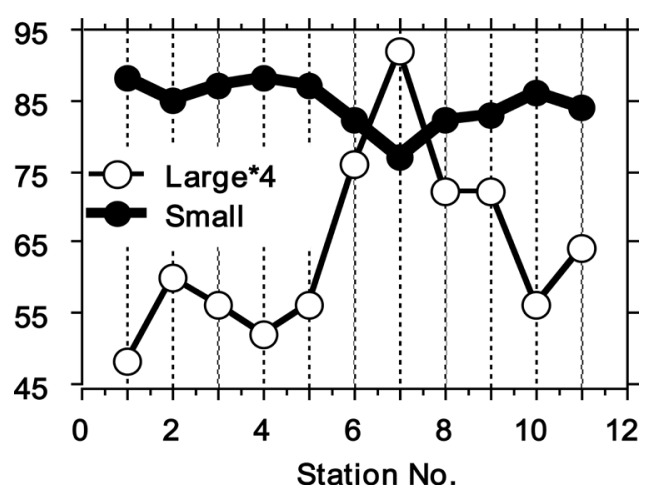

Figure 2. Numerical percentage $(\%)$ densities of large $(\times 4)$ (Cladocera, Adult and Copepodite Cyclopoid Copepods) and small zooplankters (nauplius and rotifers) in sampling stations (1 - 11; A-K, see text and Figure 5). 
containers these trials were carried out during 60 - 90 minutes durations in $50 \mathrm{~L}$ containers and time interval of 15 - 30 minutes between sampling; and during 6 - 24 days in $5 \mathrm{~m}^{3}$ outdoor tanks and 1 - 3 days of sampling intervals; 3) Gut content analysis of freshly collected fishes and viscera removal and preservation on board. The impact of planktivorous fish feeding habits on the body size class frequency might be the reason for differ assemblages of zooplankton communities (Figure 4, Figure 5). Results in Figure 3 represent zooplankton predation by Visual Particulate feeder fishes which observe and attack the prey visually, the higher the size of the prey is the better is his visibility and capture successes by fish. Increasing water turbidity and lower visibility reduce the pressure on large body zooplankton by particulate feeders. Turbidity might be considered as a partial refuge for large body zooplankter. Figure 4 represents filter feeding behavior of planktivorous fishes: the criterion of predation successes is dominated by swimming habits where better escapers (fast swimmers) are less vulnerable (high escape-ability).

\section{Discussion}

The impact of turbidity (Water clarity) on fish feeding behavior was worldwide intensively studied. These studies

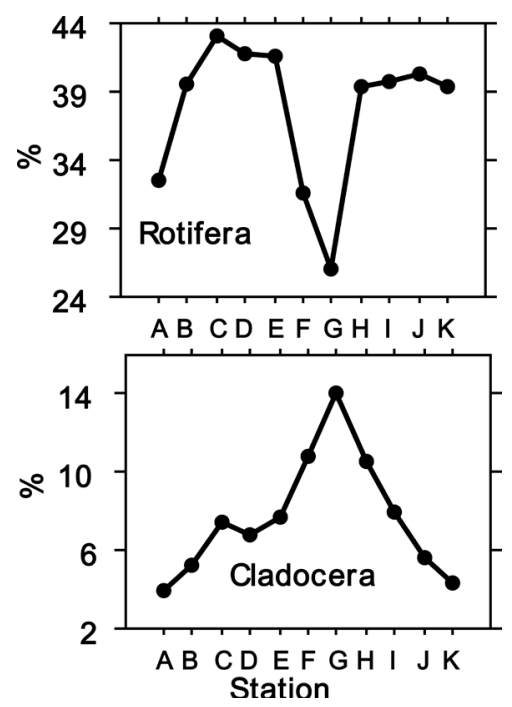

Figure 3. Numerical percentage (\%) densities of Cladocera, and Rotifera in sampling stations (A-K, see text).

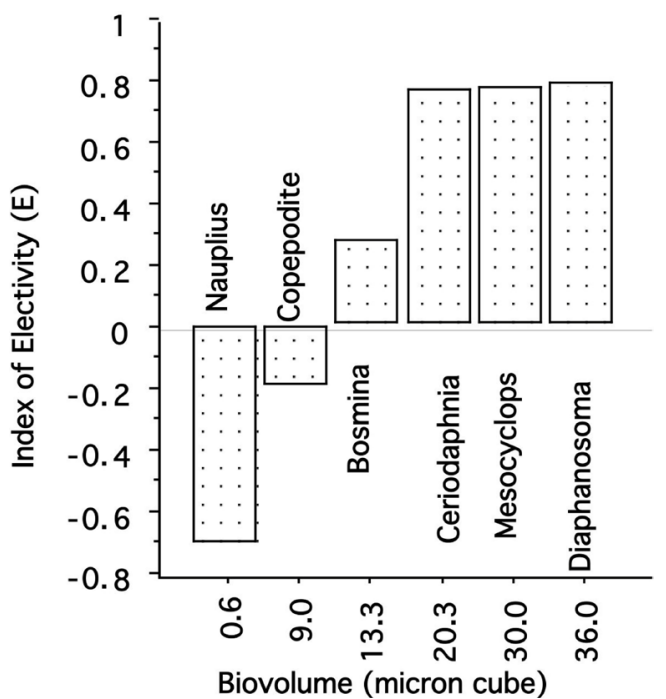

Figure 4. Particulate visual attack feeding of Sarotherodon galilaeus fingerlings: index of electivity (E) plot vs. zooplankton prey size (biovolume, $\mu^{3}$ ) (modified from [5]). 


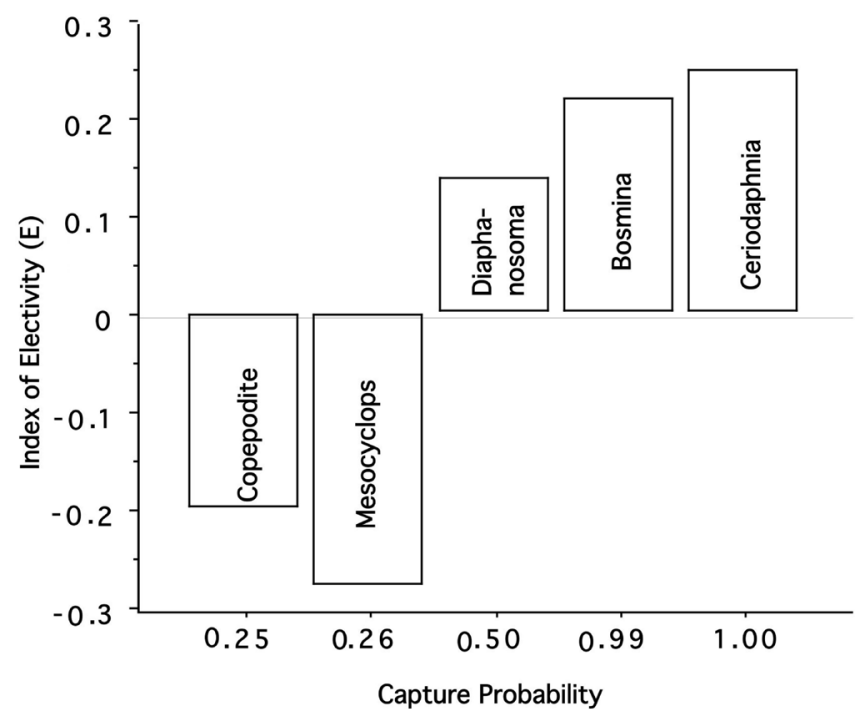

Figure 5. Filter feeding of Sarotherodon galilaeus fingerlings: index of electivity (E) plot vs. capture probability of zooplankters zooplankton prey size (biovolume, $\mu^{3}$ ) (modified from [5]).

documented decline of feeding efficiency of Particulate feeders (Visual particulate attackers). The preferential selection of large size zoplankters by Lake Kinneret fishes, especially young (larvae, fingerlings) stages of all studied species were documented by [5]-[10]. The maintenance of refuge for very small fish larvae (mostly Bleaks) by turbidity produced by densely bloomed Peridinium was documented by [11]. Several aspects of the interrelationships between fish and Plankton in Lake Kinneret were documented by [12]-[18]. Several attempts were done previously aimed at developing a model of spatial distribution of Plankton in Lake Kinneret [1] [2]. The present paper is attempted at modeling the spatial distribution of zooplankton by the linkage between water clarity and zooplankton (small and large body size) density and planktivorous fishes. The conceptual trait of those relations was tested by the evaluation of the impact of turbidity on food particles selection by fishes. Emphasizing reduction of the cascading effect on large body zooplankters by fish when the input of floods bearing suspended matter enhance turbidity in the northern part of Lake Kinneret. The significant contribution of turbidity by the Jordan River inputs was previously presented by Serruya [8]. Moreover, the ability to follow the distribution of Jordan waters in the northern part (Eastern \& Western) of Lake Kinneret by parameters detections such as high turbidity, high concentrations of Nitrates and temperatures were documented by Seruya [8]. The increase of suspended solids loads in the Jordan winter floods (indicated as dry weight or NTU measures) was also documented by The Mekorot Water Supply Company (Table 2). Under those circumstances predation pressure on Cladocera and adult Copepods is weakened. The lower efficiency of predation by making shorter the reactive distance and prey recognition was documented by [19]-[22]. [22] documented that reaction distance between predator and prey is a negative linear function of turbidity decreasing $2 \%-2.3 \%$ for each increase in NTU Units (Turbidity measure). They [21] [22] indicted that high turbidity decreases the visual acuity of fish and therefore reduces feeding rate, i.e. turbidity enhances limitation of fish vision, and visual attack feeders are interfered while large body zooplankters have survival beneficiary. [23] stated: Community structure may differ dramatically between clear-water and turbid lakes. These differences have been attributed to differences in the cascading effect of fish predation on prey populations, owing to reduce efficiency of fish predation in the presence of macrophytes. Fish predation of small animals is less efficient in the macrophyte-rich habitat. Therefore, it is suggested that significant impact on the spatial composition of zooplankton communities is Lake Kinneret is performed by fish feeding pressure trait. The food selection of Bleaks and fingerlings of Tilpias is visual attack predation and aimed mostly towards large body zooplankton. Adult Tilapias and other planktivorous fishes in the lake are filter feeders and consume suspended particles (detritus, phytoplankton and all body sizes of zooplankton) and animals with low escape-ability and large algal colonies are preferred. In the northern and west-northern parts of the lake (where Jordan waters are the major hydrological component) [4] the size class distribution is tending towards large body animal due to the lower visibility caused by turbidity. Consequently cascading effect by visual predators is lower and filter feeders consume mostly small vulnerable organisms with 
Table 2. External loads of Suspended Solids (SS) as measured in the Jordan River inputs into Lake Kinneret at the Huri Bridge Station [24]. Presented data are given in: NTU units, total monthly loads (ton) and monthly averages of concentration (ppm) during pre (October) and post (April) and during flood season (January-March).

\begin{tabular}{cccc}
\hline Month & ppm & ton & NTU \\
\hline October & 27 & 407 & 28 \\
January & 167 & 13,654 & 27 \\
February & 70 & 4333 & 39 \\
March & 64 & 4326 & 16 \\
April & 29 & 1085 & 14 \\
\hline
\end{tabular}

low escape capabilities. In other parts of the lake (excluding the shallows) the pressure of fish consumption on zooplankton is better balanced between filter and particulate feeders. In the shallows, the major impact is probably due to macrophytes [23] where reduced visibility lower feeding efficiency of fish larvae and fingerlings.

The impact of Jordan River winter floods on water clarity in the northern part of Lake Kinneret is exemplified by data given in [24] and summarized here (Table 2).

Moreover, information on spatial and bathymetrical Fish densities distribution in Lake Kinneret given in [25] confirm highest concentrations in the northern (North-Eastern and Western) part of the lake in winter. Highest densities of fish shoals were recorded (Echo-Survey) [25] at the depths of 5 - $10 \mathrm{~m}$ during day time. Consequently it is suggested that cascading pressure of planktivorous fishes on zooplankton is closely related to the most turbid part of Lake Kinneret and the feeding activity is done during day time. Therefore visibility is significant.

\section{Summary}

Spatial survey of zooplankton community structure was carried out in Lake Kinneret. Counted animals were sorted by two groups: 1) Large body, included Copepodite and adult Cyclopoid Copepods; and 2) Small, included copepods nauplii and rotifers. It was found that water clarity affected the size composition of the zooplankton community. In the north-eastern and north western where water clarity is low the \% of large organisms is higher than in other parts of the lake where turbidity is lower and the relative portion of large animals is declining. It is suggested that the feeding habits of planktivorous fishes have an influence on this phenomena.

\section{References}

[1] Kalikhman, I., Walline, P. and Gophen, M. (1992) Simultaneous Patterns of Temperature, Oxygen, Zooplankton and Fish Distribution in Lake Kinneret, Israel. Freshwater Biology, 28, 337-347. http://dx.doi.org/10.1111/j.1365-2427.1992.tb00592.x

[2] Yacobi, Y.Z., Kalikhman, I., Gophen, M. and Walline, P. (1993) The Spatial Distribution of Temperature, Oxygen, Plankton and Fish Determined Simultaneously in Lake Kinneret, Israel. Journal of Plankton Research, 15, 589-601. http://dx.doi.org/10.1093/plankt/15.6.589

[3] Gophen, M. and Azoulay, B. (2002) The Trophic Status of Zooplankton Communities in Lake Kinneret (Israel). Verhandlungen des Internationalen Verein Limnologie, 28, 836-839.

[4] Serruya, S. (1981) The Mixing Pattern of the Jordan River in Lake Kinneret. Limnology and Oceanography, 19, 175181. http://dx.doi.org/10.4319/lo.1974.19.2.0175

[5] Drenner, R.W., Vinyard, G.L., Gophen, M. and McComas, S.R. (1982) Feeding Behaviour of the Cichlid Sarotherodon galilaeus: Selective Predation on Lake Kinneret Zooplankton. Hydrobiologia, 87, 17-20. http://dx.doi.org/10.1007/BF00016658

[6] Gophen, M. and Threlkeld, S.T. (1989) An Experimental Study of Zooplankton Consumption by the Lake Kinneret Sardine. Archiv für Hydrobiologie, 115, 91-95.

[7] Gophen, M. and Landau, R. (1977) Trophic Interactions between Zooplankton and Sardine (Mirogrex terraesanctae) Populations in Lake Kinneret, Israel. Oikos, 29, 166-174. http://dx.doi.org/10.2307/3543309

[8] Serruya, C., Gophen, M. and Pollingher, U. (1980) Lake Kinneret: Carbon Flow Patterns and Ecosystem Management. Archiv für Hydrobiologie, 88, 265-302.

[9] Gophen, M., Drenner, R.W. and Vinyard, G.L. (1983) Cichlid Stocking and the Decline of the Galilee St. Peter’s Fish (Sarotherodon galilaeus) in Lake Kinneret (Israel). Canadian Journal of Fisheries and Aquatic Sciences, 40, 983-986. 
http://dx.doi.org/10.1139/f83-124

[10] Gophen, M. (1985) Effect of Fish Predation on Size Class Distribution of Cladocerans in Lake Kinneret. Verhandlungen des Internationalen Verein Limnologie, 22, 3104-3108.

[11] Gophen, M., Walline, P.D. and Azoulay, B. (1991) Association between Larval Sardines and Peridinium Patches in Lake Kinneret, Israel. Verhandlungen des Internationalen Verein Limnologie, 24, 2537-2540.

[12] Gophen, M. (1986) Fisheries Management in Lake Kinneret (Israel). Proceedings of the Annual Meeting of North American Lake Management Society, Lake Geneva, 13-16 November 1985, 327-332. http://dx.doi.org/10.1080/07438148609354652

[13] Gophen, M. (1987) Fisheries Management, Water Quality and Economic Impacts: A Case Study of Lake Kinneret. Proceedings of the World Conference on Large Lakes, Mackinac Island, 18-21 May 1986, 5-24.

[14] Gophen, M. (2004) Ecohydrological Management of Lake Kinneret: A Case Study. Ecohydrology and Hydrobiology, 4, 397-408.

[15] Gophen, M. (2015) Ecophysiology of Lake Kinneret (Israel) Zooplankton. Open Journal of Ecology, 5, 187-198. http://dx.doi.org/10.4236/oje.2015.55016

[16] Drenner, R.W., Hambright, J.D., Vinyard, G.L., Gophen, M. and Pollingher, U. (1987) Experimental Study of SizeSelective Phytoplankton Grazing by a Filter-Feeding Cichlid and the Cichlid's Effects on Plankton Community Structure. Limnology and Oceanography, 32, 1138-1144. http://dx.doi.org/10.4319/lo.1987.32.5.1138

[17] Vinyard, G.L., Drenner, R.W., Gophen, M., Pollingher, U., Winkleman, D.L. and Hambright, K.D. (1988) An Experimental Study of the Plankton Community Impacts of Two Filter-Feeding Cichlids, the Galilee Saint Peter's Fish (Sarotherodon galilaeus) and Blue Tilapia (Tilapia aurea). Canadian Journal of Fisheries and Aquatic Sciences, 45, 685690. http://dx.doi.org/10.1139/f88-082

[18] Gophen, M., Serruya, S. and Spataru, P. (1990) Zooplankton Community Changes in Lake Kinneret (Israel), during 1969-1985. Hydrobiologia, 191, 39-46. http://dx.doi.org/10.1007/BF00026037

[19] Rowe, M., Essig, D. and Jessup, B. (2003) Guide to Selection of Sediment Targets for Use in Idaho TMDLS. Idaho Department of Environmental Quality, Boise, 89 p.

[20] Berg, I. and Northcote, T.G. (1985) Changes in Territorial, Gill-Flaring and Feeding Behavior in Juvenile Coho Salmon (Oncorhynus kisutch) Following Short-Term Pulses of Suspended Sediments. Canadian Journal of Fisheries and Aquatic Sciences, 42, 1410-1417. http://dx.doi.org/10.1139/f85-176

[21] Barret, J.C., Grossman, G.D. and Rosenfeld, F. (1992) Turbidity-Induced Changes in Reactive Distance of Rainbow Trout. Transaction of the American Fisheries Society, 121, 437-443. http://dx.doi.org/10.1577/1548-8659(1992)121<0437:TICIRD>2.3.CO;2

[22] Redding, J.M., Schreck, C.B. and Everest, F.H. (1987) Physiological Effects on Coho Salmon and Steelhead of Exposure to Suspended Solids. Transaction of the American Fisheries Society, 116, 737-744. http://dx.doi.org/10.1577/1548-8659(1987)116<737:PEOCSA>2.0.CO;2

[23] Van de Meutter, F., De Meester, L. and Stoks, R. (2005) Water Turbidity Affects Predator-Prey Interactions in a FishDamselfly System. Oecologia, 144, 327-336. http://dx.doi.org/10.1007/s00442-005-0050-3

[24] Rom, M., Berger, D., Sarusi, F. and Telsch, B. (2011) Kinneret Drainage Basin Report on Winter 2009/10. Mekorot Water Supply Company, 66 p. (In Hebrew)

[25] KKL (2011) Annual Report. Kinneret Limnological Laboratory, 148 p. (In Hebrew) 


\section{Answers (Notes) to Referee 1}

1) Figure 3 \& Figure 4 were truly modified from previous one of my previous studies but are essential to the present paper . Therefore I decided to present a modification of those two figures.

2) Unfortunately similar studies on interactions between zooplankton and fish were not performed in recent years. Nevertheless citations were taken from studies carried out during the 20001's (2002, 2004, 2011, 2015, 2003, 2005, 2011). I do hope that publication of this study might give a push for more similar studies nowdays.

3) I added information and text on two essential issues: turbidity in the northern part of the lake and fish high densities in those areas.

4) I gave the MS to a mother English speaker for language polishing and he did the best he can. The figures were re-ordered respectively.

5) The legend of Large 4 mean the data in the figure include \% of "Large" organisms are 4 times higher (multiplied) for the ability of reasonable graphic presentation.

6) I added legends for the lettering (A-J)—numbers (1 - 11) respective readability.

7) I added information on turbidity as requested.

The data presented in the paragraph after Table 1 is not of a type that can be assembled in a table therefore I left it as it is. 